\title{
Analysis of superficial groundwater quality in the ex- manganese mine in the kliripan hamlet of hargorejo village, kokap district, kulonprogo.
}

\author{
$1^{\text {st }}$ Sudaryanto ${ }^{1}, 2^{\text {nd }}$ Suyono $^{2}, 3^{\text {th }}$ M. Iqbal ${ }^{3}, 4^{\text {th }}$ Hasywir Thaib Siri ${ }^{4}$ \\ daryo_ta@yahoo.co.id ${ }^{1}$ \\ Jurusan Teknik Pertambangan, FTM, UPN "Veteran” Yogyakarta",2,3,4
}

\begin{abstract}
Manganese ore mining in the Kliripan area was initially carried out by the Dutch colonial government until the independence of the Republic of Indonesia. After independence the Manganese ore mining activity in Kliripan was continued by the Government of Indonesia until the end of 1983. The quality of water consumed, as well as the quality of water in lakes, streams, rivers and oceans, is an important parameter in determining the overall quality of life. Water quality is determined by the solute and the gas dissolved in the water, as well as the suspended material and floating on the water.

This study aims to determine the physical characteristics and chemical characteristics of water taken from community wells around the former Manganese mining openings. The research results obtained are, water can be consumed by the community or meet the requirements set by the Republic of Indonesia Government Health Regulation No. 492 / Menkes / Per / IV / 2010 concerning Requirements for Drinking Water Quality. There are no factors that affect the quality of the water that is around the hole that was opened by the mining of manganese ore in the Kliripan Hamlet, Hargorejo Village, Kokap District, Kulon Progo Regency.
\end{abstract}

Keywords: Water, Quality, Manganese

\section{Introduction}

Manganese ore mining activities in the Kliripan sub-district of Kulonprogo had stopped around 1983. The mining system uses underground mining systems, while the underground mining method uses the Gophering or Coyoting method. At the Kliripan mine there are two main opening holes, namely the Vertical Shaft (PTPM) and the Inclined Shaft (Sunoto). The existence of a former mining manganese ore in the Kliripan Hamlet, Kulonprogo Regency may be able to affect the quality of ground water in the community dug wells around the former opening hole of Manganese ore mining. Groundwater is a component of a hydrological cycle that involves many aspects of biogeophysics, even political and socio-cultural aspects that determine groundwater in a region (Pusat Lingkungan Geologi, 2007). Changes in land use / land use will affect the availability of groundwater both in quantity and quality. Naturally, groundwater contains a certain amount of chemical elements derived from the ongoing process of the hydrologic cycle from the formation of water vapor in the atmosphere to during its drainage on the surface and subsurface.

The usefulness of water for certain purposes is determined by water quality. If human activities change the quality of natural water so that it is no longer suitable for use that was previously appropriate, the water is said to be polluted or contaminated. It should be noted that in many areas water quality has been affected by human activities, but water can still be used (Fetter, 1988). Water quality is one aspect that is increasingly being considered, with water as one of the infrastructures that support tourism conditions. 
Water quality is one aspect that is increasingly being considered, with water as one of the infrastructures that support tourism conditions. Likewise in the daily life of the people in Kliripan in the use of ground water is not only for washing clothes and bathing, but also for washing food and drinking water. Research on water quality in the Kliripan sub-village has never been done. So it is necessary to do research on the quality of ground water to determine the quality of ground water contained in the dug wells of residents around the former opening hole manganese ore mining.

There is a plan to utilize the opening holes of the former Manganese ore mining, one of which is for Geotourism purposes and also an underground mining practice for students of Mining Engineering Study Program and other related Study Programs.

If the above can be done then of course it will have an impact on increasing the income of the community around the opening hole. Therefore, research needs to be done from various fields of expertise, including hydrogeology. This research was conducted to determine the quality of ground water in the community dug wells around the former opening hole of manganese ore mining.

\section{Formulation of The Problem}

The underground opening hole of the former Manganese ore mine in Kliripan is currently in a state of mostly submerged by mine water. So to find out more details about the condition of the opening hole of the former Manganese ore mining cannot be done. Including the desire to utilize the former mine opening holes for the benefit of Geotourism and also a place of practice for students who are related to mining science.

Related to the above, the problems to be studied in more detail are the quality of ground water (physical parameters and chemical parameters) in the community dug wells and the factors that affect the quality of ground water in the community dug wells around the former Manganese ore mining pit, Kliripan.

\section{Research Purposes}

The purpose of conducting research of ground water quality parameters in the study area is to analyze ground water quality parameters and the factors that affect groundwater quality in residents dug wells, as well as knowing the distribution of the main parameters of groundwater quality in dug wells residents around the hole formerly opened by Manganese ore mining in Kliripan, Kulon Prgogo Regency.

\section{Method}

Research on the parameters of ground water quality in the community dug wells around the hole opened by Manganese ore mining in Kliripan Hamlet, Kokap District, Kulon Progo Regency can be seen in Figure 1 using the fishbone diagram

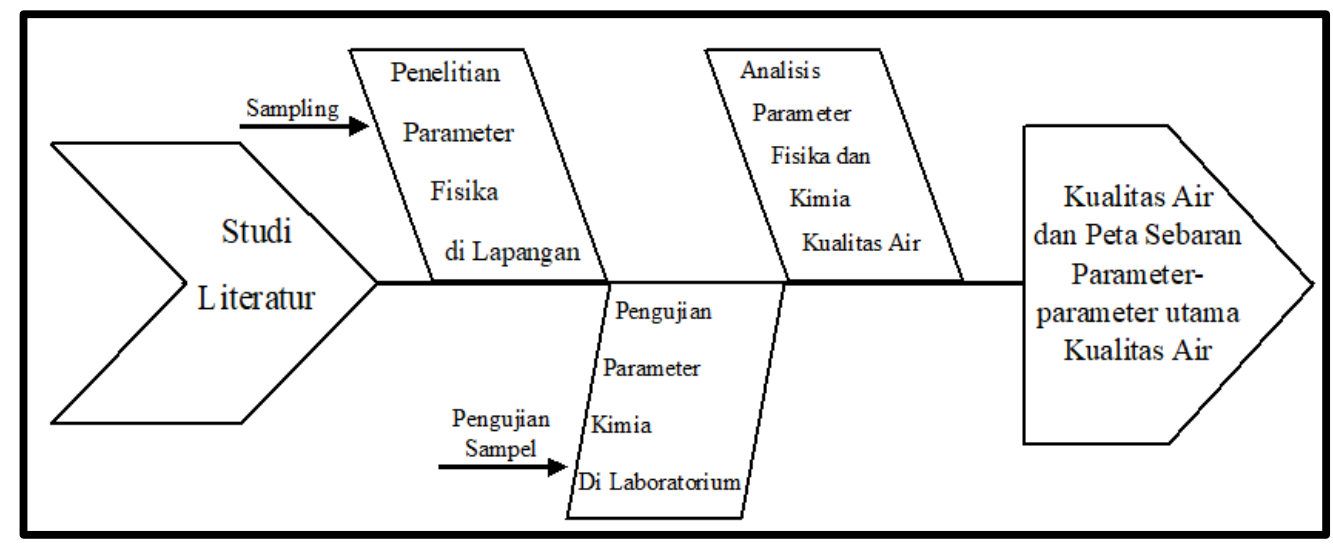

Fig. 1. Water Quality Research Methods 


\section{Regional Locations And Displays}

Administratively the research location is located in the village of Hargorejo, Dusun Kliripan located in Kokap District, Kulon Progo Regency. Geographically Kulon Progo Regency is located between 70 38'42 "- 70 59'3" South Latitude and 1100 1'37 "- 1100 16'26" East Longitude, is part of the Yogyakarta Special Region Province which is located in the westernmost part and is limited by: North side: Magelang Regency Southern Side: Indian Ocean West side: Purworejo Regency East side: Sleman Regency and Bantul Regency. The research location can be seen in Figure 2. Map of Regional Achievement Research Location.

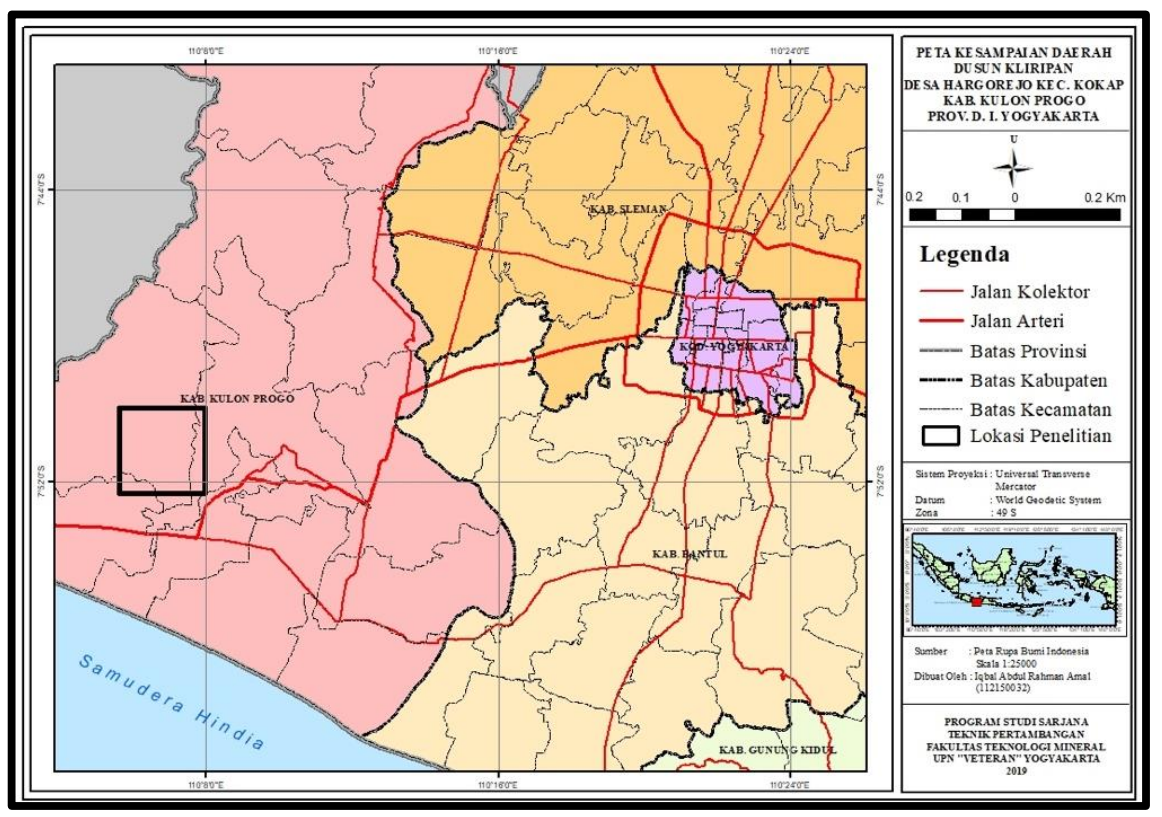

Fig. 2. Map of Regional Success in Research Location

The accomplishment of the research area is approximately $40 \mathrm{~km}$ from the city of Yogyakarta. The time that can be taken is 1 hour - 1 hour 30 minutes by road trip. The location of the study area can be reached by using two-wheeled vehicles and four-wheeled vehicles.

\section{Results And Discussion}

Water quality is basically talking about water quality characteristics that come from natural water sources, then the description of water quality will begin by discussing physical characteristics such as temperature and dissolved material in water and other characteristics (chemistry) formed by the compounding of organic materials and non-organic which has an important role as an indicator of water quality (Asdak, 2007).

Testing the quality of dug wells around the former opening hole of Manganese ore mining in Kliripan Hamlet, Hargorejo Village, Kulon Progo District was conducted through direct field testing to determine the parameters of odor, color, taste, temperature, TDS (Total Dissolved Solids) and DHL (Power of Conductivity). Electricity) The degree of acidity $(\mathrm{pH})$ of water samples at each well point and testing of chemical characteristics at the Water Quality Monitoring Laboratory, Bantul District Health Office. Testing the chemical characteristics of water in the Laboratory consists of iron $(\mathrm{Fe})$, Carbonate $\left(\mathrm{CaCO}^{3}\right)$, Flouride $(\mathrm{F})$, Chloride $(\mathrm{Cl})$, Manganese $(\mathrm{Mn})$, Sulfate $\left(\mathrm{SO}^{4}\right)$, Nitrate $\left(\mathrm{NO}^{3}\right)$ dan Nitrite $\left(\mathrm{NO}^{2}\right)$.

Data was collected from the 13th to the 17th of February 2019 with data collection from 07.00 to 15.00 West Indonesia Time (West Indonesia Time). Data taken at Kliripan Hamlet in Hargorejo Village, Kokap District were taken directly and indirectly. Data taken directly in the form of Physical 
Parameters data, data on the degree of acidity / power of hydrogen $(\mathrm{pH})$ and ground water level. Data taken indirectly is Chemical Parameter data through the measurement of the Water Quality Monitoring Laboratory of the Bantul District Health Office and rainfall data. The test does not include chemical additional parameters, biological parameters and radioactive parameters.

The results of testing physical parameters and chemical parameters of water quality can be seen in Table 1 regarding the Results of Water Quality Testing Based on Government Regulation RI Health No. 492 / Menkes / Per / IV / 2010 Regarding Drinking Water Quality Requirements.

Tabel 1. Water Quality Testing Results Based on Government Regulation RI Health No. 492 / Menkes / Per / IV / 2010 Regarding Drinking Water Quality Requirements

\begin{tabular}{|c|c|c|c|c|}
\hline No. & Jenis Parameter & Satuan & $\begin{array}{c}\text { Kadar } \\
\text { Maksimum } \\
\text { yang } \\
\text { Diperbolehkan } \\
\end{array}$ & $\begin{array}{l}\text { Hasil yang } \\
\text { Diperoleh }\end{array}$ \\
\hline \multirow[t]{6}{*}{1} & Paramteter Fisik & & & \\
\hline & Bau & & Tidak berbau & Tidak berbau \\
\hline & Warna & & Tidak berwarna & Tidak berwarna \\
\hline & $\begin{array}{l}\text { Total zat padat terlarut } \\
\text { (TDS) }\end{array}$ & $\mathrm{mg} / \mathrm{l}$ & 500 & 358,57 \\
\hline & Rasa & & Tidak berasa & Tidak berasa \\
\hline & Suhu & ${ }^{\circ} \mathrm{C}$ & Suhu udara \pm 3 & 29,5 \\
\hline \multirow[t]{10}{*}{2} & Parameter kimiawi & & & \\
\hline & Besi (Fe) & $\mathrm{mg} / \mathrm{l}$ & 0,3 & 0,017 \\
\hline & Kesadahan $\left(\mathrm{CaCO}^{3}\right)$ & $\mathrm{mg} / \mathrm{l}$ & 500 & 222,57 \\
\hline & Khlorida $(\mathrm{Cl})$ & $\mathrm{mg} / \mathrm{l}$ & 250 & 44,25 \\
\hline & Mangan (Mn) & $\mathrm{mg} / \mathrm{l}$ & 0,4 & 0,097 \\
\hline & Derajat Keasaman/pH & $\mathrm{mg} / \mathrm{l}$ & $6,5-8,5$ & 6,6 \\
\hline & Sulfat $\left(\mathrm{SO}^{4}\right)$ & $\mathrm{mg} / \mathrm{l}$ & 250 & 23,38 \\
\hline & Zat organik $\left(\mathrm{KMnO}_{4}\right)$ & $\mathrm{mg} / \mathrm{l}$ & 10 & 1,764 \\
\hline & Nitrit (sebagai $\mathrm{NO}_{2}{ }^{-}$) & $\mathrm{mg} / \mathrm{l}$ & 3 & 0,29 \\
\hline & Nitrat $\left(\right.$ sebagai $\mathrm{NO}_{3}{ }^{+}$) & $\mathrm{mg} / \mathrm{l}$ & 50 & 19,885 \\
\hline
\end{tabular}

Note: The results obtained are an average value of 7 sample well points Source: Personal Analysis Results Data, 2019

Based on the test results obtained, all water samples taken in the study area can meet the physical parameters and chemical parameters of drinking water quality determined by the Republic of Indonesia Government Health No. 492 / Menkes / Per / IV / 2010 concerning Drinking Water Quality Requirements, namely the physical parameters of Odor, Color, Total Dissolved Solids (TDS), Taste and Temperature (oC), chemical parameters pH (Degree of Acidity or power of hydrogen), Iron (Fe), Hardness (CaCO3), Chloride (Cl), Manganese (Mn), Sulfate (SO4), Organic Substances (KMnO4), Nitrite (NO2) and Nitrate (NO3).

\section{Map of Distribution of Water Quality Parameters}

Distribution of DHL Physical Parameters (Electrical Conductivity) Distribution of physical parameters of DHL (Electrical Conductivity) of water quality in Figure 3 which shows the results of water quality parameters in the study area. Seen at the well points SG $2(766 \mu \mathrm{S} / \mathrm{cm}), \mathrm{SG} 3$ $(780 \mu \mathrm{S} / \mathrm{cm})$ and SG $8(760 \mu \mathrm{S} / \mathrm{cm})$ have higher electrical conductivity values marked in brown on the distribution map. Well points SG $1(680 \mu \mathrm{S} / \mathrm{cm}), \mathrm{SG} 4(686 \mu \mathrm{S} / \mathrm{cm}), \mathrm{SG} 6(660 \mu \mathrm{S} / \mathrm{cm})$ and SG 7 (660 $\mu \mathrm{S} / \mathrm{cm})$ 


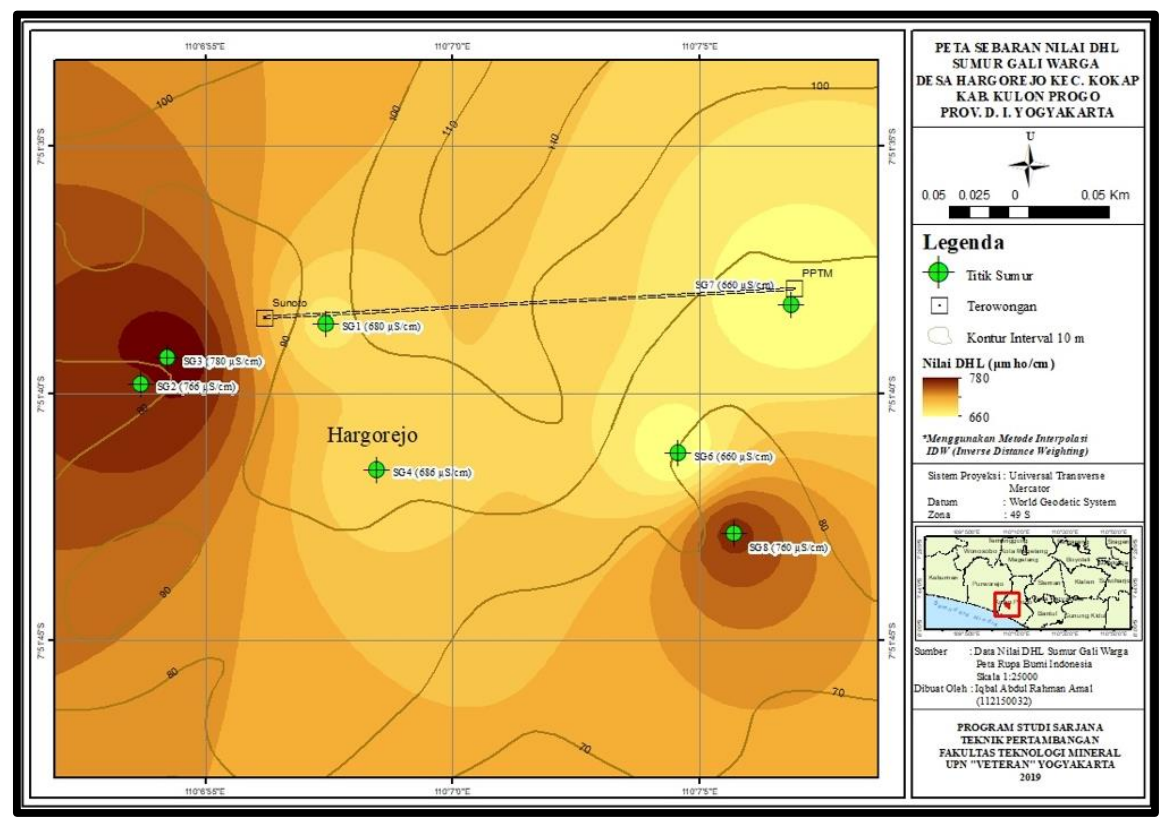

Fig. 3. DHL Physical Distribution Parameter (Electric Conductivity)

The points in Figure 5.13 are marked on the distribution map with the highest to lowest values brown $(780 \mu \mathrm{S} / \mathrm{cm})$, yellow-brown $(720 \mu \mathrm{S} / \mathrm{cm})$ and yellow $(660 \mu \mathrm{S} / \mathrm{cm})$. According to Davis and Wiest (1996), the physical parameters of DHL (Electric Conductivity) in this area are included in the Groundwater group with a conductivity value of $50-50,000 \mu \mathrm{S} / \mathrm{cm}$. For more details, map the distribution of DHL's physical parameters.

Distribution of physical parameters of temperature / groundwater temperature in Figure 4 which shows the results of the parameters of water quality in the study area. Seen at the well point SG $8(32 \mathrm{oC})$ to the south has the highest value marked in red on the distribution map. This is due to the influence of the weather which is water sampling is carried out during the day with high air temperatures.

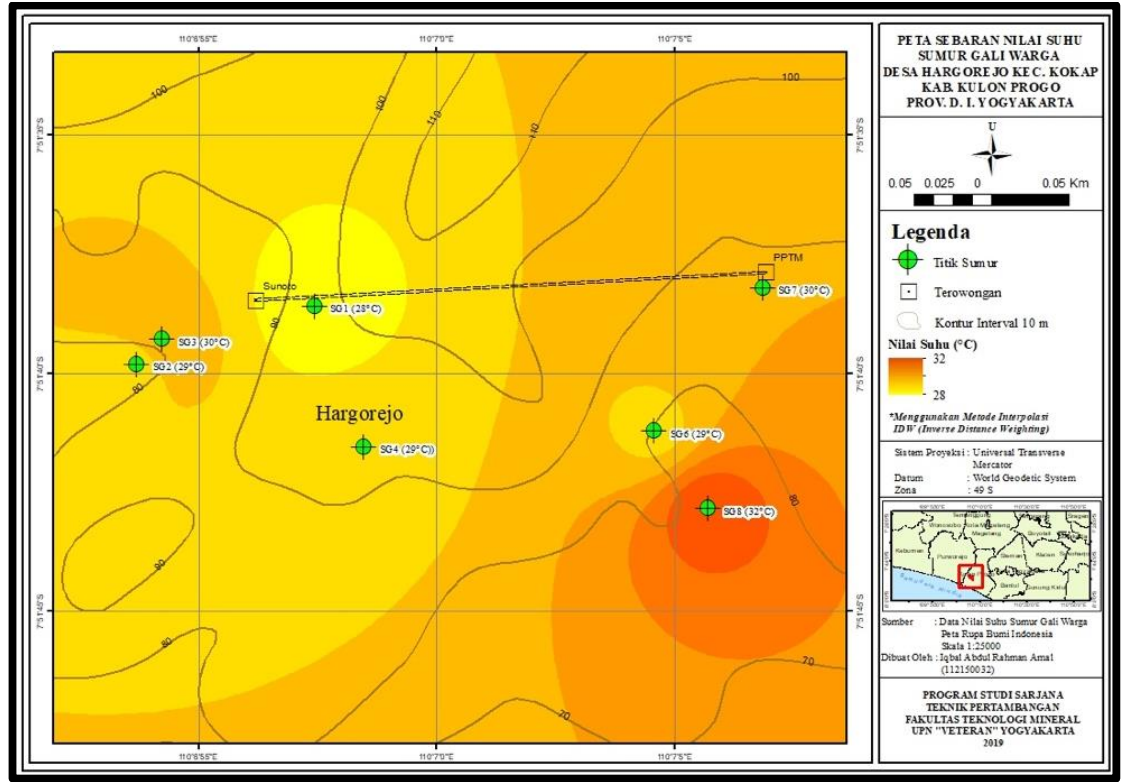

Gambar 4. Peta Sebaran Parameter Fisik Suhu 
The temperature at the well points SG 1, SG 2, SG 3, SG 4, SG 6 and SG 7 has a temperature value $\leq 30 \mathrm{oC}$ which is symbolized by a range of light orange $(30 \mathrm{oC})$ and yellow $(28 \mathrm{oC})$. According to the Republic of Indonesia Government Health Regulation No. 492 / Menkes / Per / IV / 2010, a suitable temperature as a determinant of drinking water quality is the temperature of $\pm 3 \mathrm{oC}$.

Distribution of Physical Parameters.

\section{Total Dissolved Solids (TDS)}

Distribution of physical parameters of Total Dissolved Solids (TDS) of ground water in Figure 5 which shows the results of water quality parameters in the study area. Based on the distribution map, the TDS parameters with high values are symbolized by the gradation of red $(390 \mathrm{mg} / \mathrm{L})$ at the well points SG 2 (380 mg / L) and SG 3 (390 mg / L) which are located on the west. TDS parameters with values $<380 \mathrm{mg} / \mathrm{L}$ are symbolized by gradations of orange $(360 \mathrm{mg} / \mathrm{L})$ and green (330 mg / L) found in wells SG 1 (343 mg / L), SG 4 (341 mg / L) ), SG 6 (330 mg / L), SG 7 (350 $\mathrm{mg} / \mathrm{L})$ and SG 8 (376 $\mathrm{mg} / \mathrm{L})$.

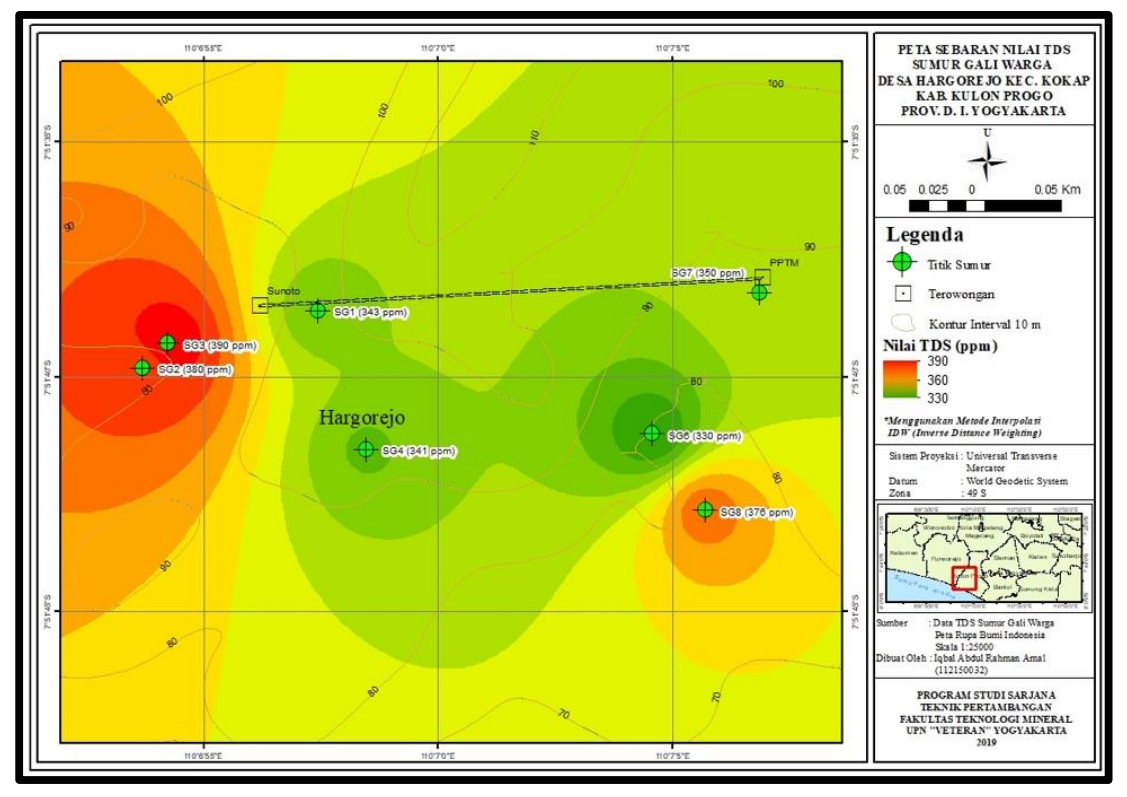

Fig. 5. Peta Sebaran Parameter Fisik Total Dissolved Solids (TDS)

Physical parameters of groundwater TDS in the study area can be classified into fresh water. Based on the Republic of Indonesia Government Health Regulation No. 492 / Menkes / Per / IV / 2010, the maximum permissible TDS value is $500 \mathrm{mg} / \mathrm{L}$ so that the water in the area is suitable for use as clean water and drinking water.

\section{Distribution of Chemical Parameters Acidity (pH)}

Distribution of chemical parameters of the acidity $(\mathrm{pH})$ of ground water in Figure 6 which shows the results of the water quality parameters in the study area. Based on the $\mathrm{pH}$ distribution map, the pH values at the well points SG 2 (6.6), SG 3 (6.6) and SG 4 (6.6) have the same pH value which is symbolized by a gradation in red. Whereas at the well points SG 1 (6.7), SG 6 (6.7), SG 7 (6.7) and SG 8 (6.7) are symbolized by gradations of green. 


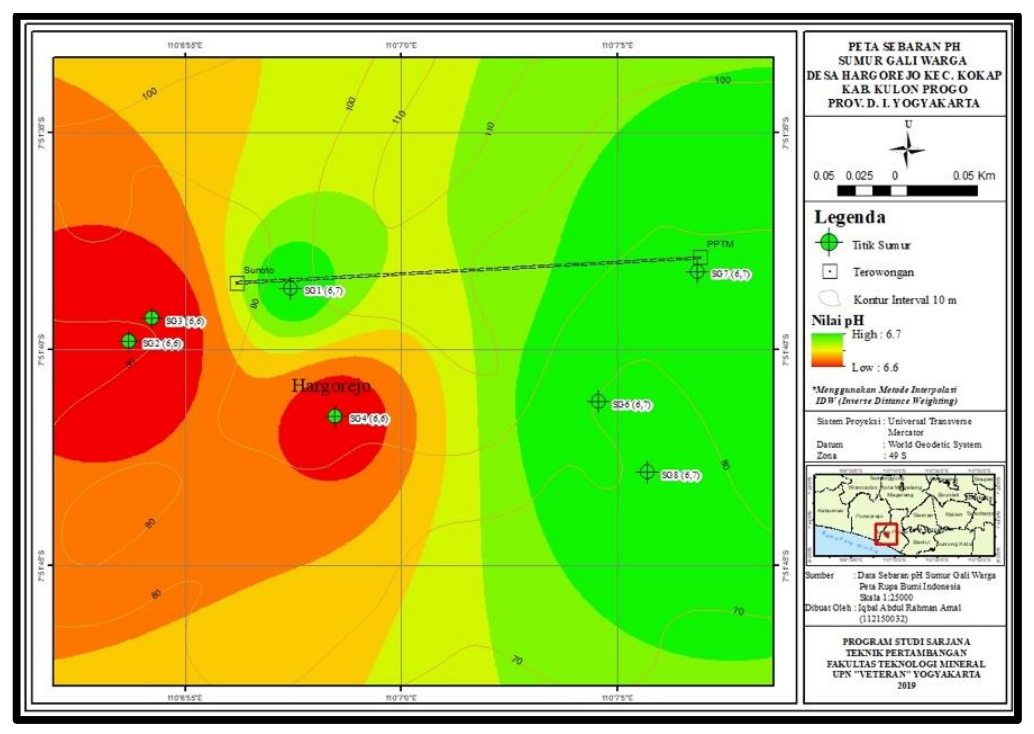

Fig. 6. Peta Sebaran Parameter Kimia Derajat Keasaman (pH)

The $\mathrm{pH}$ value of ground water in the study area did not show any significant difference with the difference in $\mathrm{pH}$ value of 0.1 . According to the Republic of Indonesia Government Health Regulation No. 492 / Menkes / Per / IV / 2010 concerning the parameters of drinking water quality requirements, water in the area is suitable for use as clean water and drinking water based on chemical parameters of $\mathrm{pH}$.

\section{Analysis of Factors Affecting Water Quality}

Water quality conditions in one place are different from water quality conditions in other places. According to Suyono (2004), factors that affect groundwater quality in general can be grouped into natural and non-natural (human) factors. Factors affecting water quality are climate, rock / geological conditions, vegetation and human factors. 765/5000

Based on the results of the study, the dug wells tested were plantations or agriculture but were still far from the position of SG dug wells 3 . The results of testing the value of Nitrate and organic matter content $(\mathrm{KMnO} 4)$ values that were below the maximum threshold determined by the Government of Health RI No. 492 / Menkes / Per / IV / 2010 concerning Requirements for Drinking Water Quality. This shows that vegetation and human factors in the use of fertilizers are not factors that affect water quality in the area. The study area does not show any climatic factors that affect water quality due to long distances from the coast or sea, types of industry that do not cause pollution, and the absence of volcanic activity.

One of the factors that influence water quality in the Kliripan area is the Rock / Geology factor. The study area was conducted around the former opening hole of Manganese ore mining in Kliripan. The test results show that the composition of Manganese (Mn) in water is far below the maximum threshold determined by the Government of the Republic of Indonesia Health No. 492 / Menkes / Per / IV / 2010 concerning Drinking Water Quality Requirements containing Manganese (Mn) values ranging from $0.06 \mathrm{mg} / \mathrm{L}$ to $0.18 \mathrm{mg} / \mathrm{L}$. This shows that the presence of Manganese $(\mathrm{Mn})$ in the well around the former opening hole of manganese ore mining does not affect water quality.

Based on the test results, the rock / geology factor does not affect the water quality in the study area. This is because all physical parameters and chemical parameters that affect rock / geological conditions show results that are below the maximum threshold determined by the Indonesian Health Government No. 492 / Menkes / Per / IV / 2010 concerning Requirements for Drinking Water Quality.

\section{Conclusion}

The results of water quality research in the community dug wells around the former hole opening of the Manganese ore mining, all water samples meet physical parameters and chemical 
parameters set by the Government of the Republic of Indonesia Health No. 492/Menkes/Per/IV/2010 concerning Requirements for Drinking Water Quality. There are no factors that affect the quality of water in the community dug wells in the former Manganese ore mining openings in Kliripan Hamlet, Kokap District, Kulon Progo Regency.

\section{References}

[1] Asdak, Chay. 2007. Hidrologi dan Pengelolaan Daerah Aliran Sungai. Yokyakarta: Gajah mada University Press.

[2] Depkes RI, 2010. Permenkes RI No. 492/MENKES/PER/IV/2010. Tentang Persyaratan Kualitas Air Minum. Depkes RI, Jakarta.

[3] Fetter, C.W. 1988. Applied Hydrogeology. New York: McMillan Publishing Company.

[4] Pusat Lingkungan Geologi. 2007. Kumpulan Panduan Teknis Pengelolaan Airtanah. Bandung: Pusat Lingkungan Geologi.

[5] Suyono. 2004. Hidrologi Dasar. Yogyakarta: Fakulats Geografi UGM 